\title{
Faculty Members' Ethical Behaviors: A Survey Based on Students' Perceptions at Universities in Turkey
}

\author{
Kenan Ozcan ${ }^{1}$, Aydin Balyer ${ }^{2} \&$ Tayfun Servi ${ }^{1}$ \\ ${ }^{1}$ College of Education, Adiyaman University, Altinsehir, Adiyaman, Turkey \\ ${ }^{2}$ Yildiz Technical University, School of Foreign Languages Davutpasa Campus, Esenler, Istanbul, Turkey \\ Correspondence: Aydin Balyer, Yildiz Technical University, School of Foreign Languages Davutpasa Campus, \\ Esenler 34100, Istanbul, Turkey. Tel: 90-383-4901. E-mail: balyer@yildiz.edu.tr
}

Received: December 7, 2012

Accepted: January 18, 2012 Online Published: February 4, 2013

doi:10.5539/ies.v6n3p129

URL: http://dx.doi.org/10.5539/ies.v6n3p129

\begin{abstract}
As members of academic team, faculty behaviors have vital influence on students' lives at universities. This study purposes to discover students' perceptions about faculty behaviors concerning their professional responsibilities, dating/sexual harassment, behaviors inside and behaviors outside the classroom and relationship based on self-interest. The study employs both a quantitative and a qualitative research technique. Results reveal that students' considerations are negative in terms of faculty behaviors inside the classroom and faculty professional behaviors. Significant differences were discovered according to establishment dates of the universities and students' Grand Point Averages (GPAs).
\end{abstract}

Keywords: faculty, ethics, ethical behaviors, higher education

\section{Introduction}

Educators prepare members of a society into not only for its structures and functioning but also students' future lives as well. In this respect, as teachers, supervisors, evaluators, screeners and certifiers, they help their students gain knowledge, develop their skills, learn values and acquire attitudes necessary for understanding themselves. During that process, faculty-student relationships and interactions become more substantial in higher education context. As a complicated profession, teaching is also significantly implicated in ethical concerns, dilemmas and considerations (Carr, 2000; Svinicki, 1994). Hall (1973) reveals that students have very strong feelings about memories, feelings and they experience great discomfort when their moral sensibilities are violated. This makes teaching profession more crucial than any other profession. For this reason, it draws a lot of attention from the society and therefore, according to Haas, Malouf and Mayerson (1988), recent years have been marked by a rise in professional and public consciousness about ethical issues since 1980s.

\section{Definition of Ethics}

Ethics is defined as something relating to morals, treating of moral questions, morally correct and honorable ... (OUP, 2011). As a discipline, it is concerned about what in our action is moral and immoral, good and bad, acceptable and unacceptable (Colnerud, 1997; Dika \& Hamiti, 2011; Solomon, 1984). Such a definition focuses on moral principles and seems to have little relation to our daily activities as researchers, teachers, students and practitioners (Cassell \& Jacobs, 1987). It is considered that every profession has directly related to ethical concerns, codes, rules and regulations which are indicators of the willingness to accept responsibility for defining appropriate conduct and a commitment to self-regulation of members by a profession (Bersoff \& Koeppl, 1993; Chalk, Frankel \& Chafer, 1980; Koocher \& Keith-Spiegel, 1998). In spite of all these regulations, some unethical problems may arise in educational environments.

Several guidelines, codes and laws have been made by professional associations and governments to control unethical behaviors (Burgess, 2011). In this sense, the first code of ethics was published by The American Psychological Association (APA). It puts these categories of ethical standards as competence, human relations, education and training, research, publication and assessment (APA, 2002; Sandler \& Russell, 2005). Similarly, Tippins and Tobin (1993) describe these ethical virtues as honesty, courage, fairness, caring and practical wisdom. Besides, Kitchener (1985) suggested five ethical principles in dealing with students respect for autonomy, respect for the individual's decisions, doing no harm to others, benefiting others, justice and treating 
others fairly and fidelity, being loyal and trustworthy.

\section{Ethics in Educational Settings}

Education is a critical process at all levels. In this respect, providing an ethical atmosphere, confidence and trust grounded in mutual respect and behaving accordingly is crucial to successful teaching as everyone deserves respect and well-being as a central motivation for learning in educational settings (Haynes, 2002). In this process, faculty have many behaviors that effect students deeply either in a positive or negative way. However, this study focuses on some certain faculty ethical behaviors like faculty professional responsibilities, dating/sexual harassment, faculty behaviors inside and faculty behaviors outside the classroom and relationship based on self-interest. It would be helpful to describe what these behaviors are in educational atmospheres.

\subsection{Faculty Professional Responsibilities}

According to Epstein (1998), educators place greater emphasis on the affective skills in the admission and education of their students. It includes teaching a specific course and also modeling for students how to use authority and knowledge appropriately. Within this responsibility, faculty provide course material, deliver the course, inform students about the course content, assessment procedure and exam content. They also conduct tests, evaluate them fairly, give feedback and return the results in time. In addition, this work requires behaving everyone well and respectfully. Trustworthiness is another part of this role. Here, faculty are supposed to be objective and equitable in evaluation process of all students, which must be based on nondiscriminatory procedures, conducted by personnel trained to utilize appropriate methods and procedures ( Jacob \& Hartshorne, 2003; Robertson \& Grant, 1982; Strike, 1990). However, it is considered that it does not always happen in this way (Bebeau, 1993; Joseph \& Efron, 1993; Johnson, 2007).

\subsection{Faculty Dating/Sexual Harassment Behaviors}

When faculty-student relationship is concerned, dating or sexual harassment can be a problematic area to be controlled strictly. Within this issue, boundary violations relate to issues of erotic and non-erotic physical contact, self-disclosure of personal issues, and nonsexual dual relationships or any other implications and indications of sexual harassment. Despite difficulty with articulating them within the university setting, if a student is already feeling threatened by any display of power or sexuality, it becomes a marker of harassment which may affect faculty-student relationships deeply (Biaggio, Paget \& Chenoweth, 1997; Lazarus, 1994; Keith-Spiegel, Whitley, Balogh, Perkins \& Wittig, 2002; Smith \& Fitzpatrick, 1995).

\subsection{Faculty Behaviors outside the Classroom}

As soon as faculty-student relationship is concerned, there are also some relations outside the university. During these relationships, faculty may go out to cafes, pubs and spend time with their students there. Faculty can meet their students outside the school. By doing so, their students will have to spend time with them. It may be sometimes difficult for students to refuse it. Therefore, these relations should be handled with care as some misunderstandings may arise among other students and faculty. Therefore, faculty are supposed to be more careful while going to different places with their students.

\subsection{Faculty Behaviors inside the Classroom}

Faculty are expected to be kind, considerate and responsive to the students' needs without neglecting the class as a whole, ignoring discipline and providing equal learning opportunities (Barcena \& Gil, 1993; Colnerud, 1997; Smith, 1996). Here, as teachers, faculty have ethical responsibility to help ensure that all youth can attend school, learn, and develop their personal identity in the classroom environment free from discrimination, harassment, violence and abuse (NASSP, 1999). They are dealing with young people in a position of dependency called as asymmetrical power that comes from two sources: evaluation of students and expertise of subject matter (Colnerud, 1997; Churchill, 1982). In any case, they should use that power in their classrooms in an academic and fair way (Blevins-Knabe, 1992; Branstetter \& Handelsman, 2010; Cothran \& Ennis, 1997; Rupert \& Holmes, 1997). However, it is claimed that they cannot be neutral all the time (Aurin \& Maurer, 1993; Baumgarten, 1982; Dill, 1982; Kompf, 1993; Robertson \& Grant, 1982; Wilson, 1982).

\subsection{Relationships based on Self-Interest}

Faculty may have some relationships with their students based on their self-interest. During faculty student relationships, boundaries are sometimes crossed. In this context, faculty could accept expensive or inexpensive gifts, provide home telephone number, or meet with students outside the school. They may also make students do their personal work like grading exams, fixing computers and doing some other small favors. Moreover, some faculty provide senior students to check exam papers and even to conduct their classes although they don't have 
a right to do that. Indeed, faculty are expected to behave more responsibly in this issue.

\section{Ethics in Educational Settings in Turkey}

Ethical principles and rules are defined and described at different legal documents such as laws, rules and regulations designed for the Turkish educational institutions. The National Education Ministry regulates ethical standards at schools with some laws and regulations which emphasize how students should behave towards their friends, teachers and others in the society (Tebligler Dergisi, 2003). According to these legal documents, students are recommended to be kind, honest, and respectful and they are expected to obey rules. There are also regulations to design teachers' behaviors towards students. Teachers are expected to be fair, caring, respectful, honest and hardworking. In addition to these legal documents, ethics has drawn attention in researches in the Turkish educational field since 1990s. In these researches, it is generally defined as criteria to determine what is good and what is bad in people's actions as professionals. It focuses on values on what to do, what to wish and what to have. It also designs how to adapt behavior norms of any group (Yaman, Mermer \& Mutlugil, 2009).

As far as higher education is concerned, universities have determined ethical standards and formed ethical boards at departments within the framework of Bologna process recently. The Turkish Academy of Sciences (TUBA) has pioneered for faculty ethical standards and responsibilities in research, publication, and professional activities and also codes for relations towards their colleagues and students. In fact, in academia, the interactions of individuals, either from the same constituent group or from different groups, are expected to follow high ethical standards (Gercek, Güven, Ozdamar, Yelken \& Korkmaz, 2011). Here, faculty are expected to be well prepared pedagogically for their roles (Colnerud, 1997; Fritz \& Wolfgang, 1993; Zabiollah, Elmore \& Szendi, 2001).

Although there are some ethical boards, rules and regulations issued on web sites of institutions and schools, it is considered that they are defined with general terms and there are some concerns to put them into practice. Therefore, there are so many gray areas in the student-student, student-teacher, and teacher-teacher relations in the Turkish higher educational context. This causes some problems with especially faculty-students relationships as these standards have not been internalized by the members of the society even in higher education environment. Even though many researches were also conducted to raise faculty and students' awareness about this issue, most of these researches mainly focused on the topics like sexual harassment, cheating by ignoring many other daily ethical dilemmas which may occur during faculty-student interactions (Morgan \& Korschgen, 2001; Keith-Spiegel, Tabachnick \& Allen, 1993; Tabachnick, Keith-Spiegel \& Pope, 1991). Little empirical research was conducted on students' perceptions of faculty ethical behaviors in academia and outcomes of those perceptions. Bearing it on our mind, this study addresses students' perceptions of faculty ethical behaviors in terms of faculty professional responsibilities, dating/sexual harassment, relations based on self-interest, faculty behaviors inside the classroom and faculty behaviors outside the classroom. By conducting this study, it is purposed to discover faculty behaviors in the Turkish higher education context and raise awareness for unethical problems, if exist. Finally, it is aimed to recommend solutions to eliminate these problems from the system.

\section{Purpose}

Main purpose of this study is threefold. In the first place, it aims to introduce the usability of the Cross-Cultural Adaptation and Validation of the Turkey Version the Faculty Ethical Behavior Scale (FEBS) developed by Schnake, Fredenberger, and Dumler, (2004). In the second place, it purposes to discover students' perceptions about faculty behaviors regarding professional responsibilities, dating/sexual harassment, behaviors outside and inside the classroom, and relationship based on self-interest. In the third place, it targets to determine if there are any significant differences between students' perceptions in terms of university, newly and established universities, grade point average (GPA), classroom size and gender variables.

\section{Method}

As this study purposes to find out faculty ethical behaviors, it employed a survey method. The study was conducted at six different Turkish public universities in the spring term, 2011. The study employs both a quantitative and a qualitative research technique in order to collect data on students' perceptions on faculty ethical behaviors. In the quantitative part the data were collected with "Faculty Ethical Behaviors Scale" and in the qualitative part, the data were collected with some open-ended questions developed for each sub dimension.

\subsection{Sampling Procedure}

The sampling of this study was determined through purposive sampling method. The advantage of this method is that the researcher can use prior knowledge to choose respondents. It is possible to get information about the target population (Bailey, 1994). During this research, the research instruments were administered at different 
times. The faculty left the class as soon as they delivered the instruments. By doing so, it was purposed to make the students feel free from power relations. Thus, the students had a chance answer the questions more freely. As they were of volunteers and they answered the questions voluntarily. They answered the questions in the scale between 15 and 25 minutes, and they spent 25-35 minutes to write their comments on 5 open-ended questions in the qualitative part. Then, one of the students collected the forms and took to the researchers. They were also assured that their identities will never be shared with anyone else or mentioned in any part of the research. The rate of return of the scale is approximately $85 \%$ in the quantitate part and $100 \%$ in the qualitative part.

\subsection{Participants}

The participants of the quantitative part comprised of 1342 students from several universities such as Adiyaman University (365), Coruh University (174), Cumhuriyet University (252), Marmara University (194), Mersin University (175) and Sakarya University (182). Of the participants, 744 were female and 598 were male. In addition, they were from different grades as freshmen (299), second class (336), third (359) and senior grades (358) with age mean 22.4. In terms of their Grade Points Average (GPA) which is accepted as 100 the highest in Turkey, 31 of them had less than 50 GPAs, 186 between 51- 65, 586 between $66-75,442$ between $76-85$ and, 97 over 86 GPAs. Of the participants, 74 were from classes with less than 30 students, 254 from a class with 31-40 students, 394 between $41-50$ and 620 over 50 students. In the qualitative part, 133 students participated with approximate gender percentages and age mean of 21.4. It was determined by purposive sampling method which targets a particular group of people when the desired population is rare, difficult to locate and recruit for a study (Bailey, 1994).

\subsection{Data Collection and Analysis}

Faculty Ethical Behaviours Scale was developed by Schnake at al., (2004) to discover faculty ethical behaviours in terms of their behaviours inside the classroom, outside the classroom, their professional behaviours, and relationship based self-interest and sexual harassment behaviours towards students. The scale was developed on the previous studies conducted before like Tabachnick, Keith-Spiegel and Pope (1991), Keith-Spiegel, Tabachnick and Allen (1993), Morgan and Korschgen (2001). It was a 7-point Likert scale ranging from "Strongly Disagree" to "Strongly Agree" with a midpoint of nature 3. It had 29 items below five sub dimensions. These sub dimensions were behaviours inside the classroom ( 8 items), outside the classroom (6 items), faculty professional behaviours (6 items), relationship based self-interest (5 items) and sexual harassment behaviours (5 items). The scale was adapted into Turkish by Özcan and Balyer (2012) and validity and reliability study was administered. As a result of this process, it was discovered that 5-point Likert Scale form is more appropriate for the Turkish Context. The validity and reliability work was done with Exploratory Factor Analysis (EFA) and Confirmatory Factor Analysis (CFA). For EFA analysis 352 teachers participated and 402 teachers, nurses and economists participated in CFA. Here, while higher scores show negative behaviors, lower scores indicate positive ones. As a result of EFA, Cronbach Alpha Coefficient of the scale was 0.89 for the scale in general. It was 0.82 for behaviours inside the classroom, 0.70 for outside the classroom, 0.78 for faculty professional behaviours, 0.70 for relationship based self-interest and 0.76 for sexual harassment behaviours.

In this study, Cronbach Alpha Coefficient of the scale was found as 0.88 in general. It was 0.78 for behaviours inside the classroom, 0.68 for outside the classroom, 0.76 for faculty professional behaviours, 0.69 for relationship based self-interest and 0.84 for sexual harassment behaviours. It is understood that Cronbach Alpha Coefficient values of the original scale and its Turkish adapted form are approximate. Therefore, it can be said that the values are appropriate (Kline, 2011).

This study employed both a quantitative and qualitative method. In the quantitative part, survey method was used and one-way ANOVA, t-test, percentage, frequency, mean, standard deviation values and reliability analysis were done. In One-way ANOVA, Test of Homogeneity of Variance prerequisite analysis of the scale was also done ( $p>05)$. For significance of the findings among groups, Tukey multi comparison test was used. In order to determine the range normality, Kolmogorow-Simirnov Test and for reliability and other analysis, SPSS were administered.

In the qualitative part, students were asked to write anecdotes on the same sub dimensions. In this part, the data were analyzed with content analysis method. This method usually aims to gather similar data on a topic and comment on it (Bogdan \& Biklen, 1998; Buyukozturk, Kilic, Cakmak, Akgun, Karadeniz \& Demirel, 2008; Glaser, 1992; Mayring, 2000; Yildirim \& Simsek, 2000). In the present study, the data were collected using the following procedure. First, in an e-mail, 133 students were informed about the purpose of the study, and they were asked if they could participate in this research voluntarily in the qualitative part of this study with the rate on $100 \%$. Those who were invited to take part in the research consented after being assured of the 
confidentiality of the data to be gathered from them. It was promised that their identities would be kept in secret and their names would not be mentioned in any part of the study or shared with anyone else. Second, an interview was planned on an agreed-upon day with those who accepted the invitation, and the participants were visited on that date. In order to avoid power relations, the interviews were conducted outside the school. The interviews were both recorded and noted with their permission and each took approximately 25-35 minutes. Prior to interviewing, ethical approval was granted simply by providing participants consent without a board review of the study. Pseudonyms were used to maintain anonymity of both participants and institutions. In this regard, the departments were codded as Departments of Pre-School Teaching (PT), Primary School Teaching (P), Turkish Teaching (T), Psychological Counseling and Guidance (PCG), Mathematics Teaching (M), Science and Technology Teaching (ST) and Social Sciences Teaching (SS).

\section{Results}

This study was conducted to find out faculty ethical behaviors according to students' perceptions. The results obtained from both quantitive and qualitative parts are presented in this part.

Table 1. Faculty Ethical Behaviors

\begin{tabular}{llllllll}
\hline Items & & $\begin{array}{l}\text { Strongly } \\
\text { Disagree } \\
\text { disagree }\end{array}$ & & \multicolumn{2}{c}{$\begin{array}{l}\text { Strongly } \\
\text { Agree and } \\
\text { Agree }\end{array}$} & \\
\cline { 2 - 7 } & & $f$ & $\%$ & $f$ & $\%$ & $\bar{X}$ & Sd
\end{tabular}

\section{Faculty Ethical Behavior inside the Classroom}

A1 Giving lower grades to students who disagree with him/her.

Not providing alternative teaching and testing

A2 procedures for students who have learning disabilities.

A3

Giving exams which do not reflect the material covered/discussed

A4 Allowing how much he/she likes or dislikes a student to influence the student's grades.

Including false or misleading information that may

A5 hurt the student's chances when writing a letter of recommendation for the student.

A6

Including material on a test that was not covered in the lectures or assigned reading.

A7 Requiring students to disclose highly personal information in a group discussion or exercise.

\section{Relationships Based on Self- interest}

B8

Asking small favors (such as a ride home) from student.

B9 Accepting expensive gifts from students.

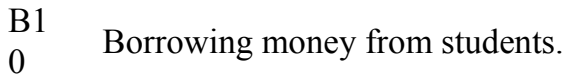

B11 Lending money to a student.

\section{Faculty Professional Responsibilities}

C1 Teaching a class without being adequately prepared 2 that day.

\begin{tabular}{|c|c|c|c|c|}
\hline 606 & 45.2 & 412 & $\begin{array}{l}30 . \\
7\end{array}$ & 2.8 \\
\hline 517 & 38.5 & 560 & $\begin{array}{l}41 . \\
7\end{array}$ & 3.0 \\
\hline 525 & 39.1 & 582 & $\begin{array}{l}43 . \\
4\end{array}$ & 3.1 \\
\hline 522 & 38.9 & 486 & $\begin{array}{l}36 . \\
2\end{array}$ & 3.0 \\
\hline 712 & 53.1 & 220 & $\begin{array}{l}16 . \\
4\end{array}$ & 2.5 \\
\hline 622 & 46.3 & 486 & $\begin{array}{l}36 . \\
2\end{array}$ & 2.8 \\
\hline 816 & 60.8 & 220 & $\begin{array}{l}16 \\
4\end{array}$ & 2.4 \\
\hline 870 & 64.8 & 288 & $\begin{array}{l}21 . \\
5\end{array}$ & 2.3 \\
\hline 902 & 67.2 & 104 & 7.8 & 2.1 \\
\hline 1126 & 83,9 & 61 & 4.5 & 1.7 \\
\hline 760 & 56.6 & 174 & $\begin{array}{l}13 . \\
0\end{array}$ & 2.3 \\
\hline
\end{tabular}

$\begin{array}{llllll}651 & 48.5 & 310 & 23 . & 2.7 & 1.1\end{array}$ 
C1 Failure to maintain regularly scheduled office

3 hours.

C1 Frequently arriving several minutes late for class

C1 5

C1 Not getting exams graded and returned until 4

6 weeks after the exam was given.

\section{Sexual Harassment Behaviours}

D1

7

Being sexually attracted to a student.

D1 Dating a student majoring in a field outside the

8 professor's teaching assignment and unlikely to ever enroll in the professor's class.

D1 Dating a student not currently enrolled in the

9 professor's class

D2 Becoming sexually involved with a student after

0 the course is completed and grades are filed.

D2 Hugging a student.

\section{Faculty Ethical Behaviours outside the Classroom}

E22 Accepting a student's invitation to a party.

E23

Beginning an on-going friendship with a student who is enrolled in the professor's class.

E24 Going to a bar with students after class.

$\begin{array}{lrrlrr}546 & 40.7 & 411 & \begin{array}{l}30 . \\ 6\end{array} & 2.9 & 1.1 \\ 701 & 52.2 & 380 & \begin{array}{l}28 . \\ 3\end{array} & 2.7 & 1.2 \\ & & & & \\ 583 & 43.4 & 537 & \begin{array}{l}40.0 \\ 0\end{array} & 3.0 & 1.3 \\ & & & & \\ 298 & 22.2 & 854 & & \\ 6 & 3.7 & 1.3\end{array}$

947

$70.6 \quad 162 \quad 12$.

$2.1 \quad 1.1$

$\begin{array}{llllll}874 & 65.1 & 153 & 11.4 & 2.2 & 1.1\end{array}$

$\begin{array}{llllll}912 & 68.0 & 125 & 9.3 & 2.1 & 1.0\end{array}$

$\begin{array}{llllll}992 & 73.9 & 114 & 8.5 & 2.0 & 1.0\end{array}$

$\begin{array}{llllll}878 & 65.4 & 208 & 15 . & 2.2 & 1.1\end{array}$

$\begin{array}{llllll}636 & 47.4 & 283 & \begin{array}{l}21 . \\ 1\end{array} & 2.6 & 1.1 \\ & & & 30 . & 2.8 & 1.1 \\ 510 & 38.0 & 408 & 4 & & \\ 868 & 64.7 & 114 & 8.5 & 2.2 & 1.0\end{array}$

The table shows means, percentage, frequency, and standard deviation values of the items. According to that, arithmetic means scores of students regarding behaviors inside the classroom were $\bar{X}=2.65 \quad(\mathrm{sd}=1.2)$, relationship based on self-interest were $\bar{X}=2.1(\mathrm{sd}=1.1)$, professional responsibilities were $\bar{X}=3.1(\mathrm{sd}=1.2)$, sexual harassment were $\bar{X}=2.1(\mathrm{sd}=1.1)$ and relationships outside the classroom were $\bar{X}=2.3(\mathrm{sd}=1.3)$. This shows that students' perceptions about faculty behaviors inside the classroom and faculty professional behaviors are negative while the others seemed normal with a few minor unethical considerations.

According to the findings, when students' views on ethical behaviors inside the classroom is concerned, $30.7 \%$ ( $\bar{X}=2.8$ ) of the participants state that their faculty give lower grades to students whom they disagree. Of these participants, $41.7 \%(\bar{X}=3.0)$ of them indicate that faculty do not provide alternative teaching and testing procedures for students who have learning disabilities and $43.4 \%(\bar{X}=3.1)$ claim that faculty give exams which do not reflect the material cover/discuss. Moreover, $36.2 \%(\bar{X}=3.0)$ of them remark that faculty allow how much they like or dislike a student to influence the student's grades, \% $16.4(\bar{X}=2.5)$ indicate that they include false or misleading information that may hurt the student's chances when writing a letter of recommendation for the student. It is also stated that \%36.2 ( $\bar{X}=2.8)$ faculty include material on a test not covered in the lectures or assigned reading. Some of these results show similarity obtained in the qualitative part. Here, students also claim that they are not given grades they deserve; they are even discriminated in terms of ethnic, regional, gender and religious difference. A student from mathematics department claims, "Some privileged students are given higher grades. Namely, some students are always privileged. We are discriminated at universities whereas universities should integrate us." Another student from the same department remarks, "One of our teachers invited me to his office. He asked me if I wanted to do masters. If so he would grade me higher. I cannot believe this."

As far as relationships based on self-interest is concerned, However, in the qualitative part, the students state that faculty ask small favors from students. A different student from mathematics department indicates, "When I went to my teacher's office to learn my exam results, he made me grade lower classes exam papers". Furthermore, 
when faculty professional responsibilities is concerned, $23.1 \%(\bar{X}=2.7)$ of the participants claim that faculty teach classes without being adequately prepared that day. Of these, $30.6 \%(\bar{X}=2.9)$ assert that faculty fail to maintain regularly scheduled office hours, $28.3 \%(\bar{X}=2.7)$ of them pronounce that some of them frequently arrive late for their classes and $40.0 \%(\bar{X}=3.0)$ of them believe that faculty miss class (3-4 weeks a term) without advance notice. Similarly, in the qualitative part, students assert that classes are boring and ineffective. They say that faculty make students teach the lessons. They also behave impolitely and do not return exams in time. Another student from mathematics department claims, "Our teacher taught 2-3 weeks and then he spent class time by praising himself. When the exams started, he told us that we were responsible for hundreds of pages. When we objected, he threatened us to increase the amount." Moreover, when sexual harassment behaviors are concerned, students do not have negative considerations about faculty. However, opposing results are found in the qualitative part. Here, many students claim that faculty touch female students physically and pull their hair. A student from primary school teaching department said, "While some teachers are talking and touching our female friends, making jokes and pulling their, we are disturbed." What is more, when behaviors outside the classroom is concerned, $21.1 \%(\bar{X}=2.6)$ of the students assert that faculty accept students' invitations to parties. Of them, $30.4 \%$ state that faculty begin on-going friendships with students enrolled in their classes. Similar results were discovered in the qualitative part. According to that another student from Psychological Counseling and Guidance department states, "Some teachers come to the cafe with us when we invite them as a matter of courtesy. He comes and plays cards with us, which disturbs everybody."

Table 2. One Way ANOVA Analysis Results in terms of GPA and Faculty ethical Behaviors

\begin{tabular}{|c|c|c|c|c|c|c|c|}
\hline Dimension & $\begin{array}{l}\text { Grade Point } \\
\text { Average }\end{array}$ & $\mathrm{n}$ & $\bar{X}$ & $\mathrm{sd}$ & $\mathrm{F}$ & $\mathrm{p}$ & $\begin{array}{l}\text { Difference } \\
\text { (Tukey) }\end{array}$ \\
\hline \multirow{5}{*}{$\begin{array}{l}\text { Ethical behavior inside } \\
\text { the classroom }\end{array}$} & Lower than 50 & 31 & 2.53 & 0.59 & 2.75 & $.027 *$ & \multirow{5}{*}{$4>3$} \\
\hline & Between 51-65 & 186 & 2.65 & 0.77 & & & \\
\hline & Between 66-75 & 586 & 2.59 & 0.72 & & & \\
\hline & Between 76-85 & 442 & 2.74 & 0.72 & & & \\
\hline & 86 and over & 97 & 2.68 & 0.69 & & & \\
\hline \multirow{5}{*}{$\begin{array}{l}\text { Relationship based on } \\
\text { self-interest }\end{array}$} & Lower than 50 & 31 & 2.85 & 0.89 & 1.322 & .260 & \\
\hline & Between 51-65 & 186 & 2.81 & 0.84 & & & \\
\hline & Between 66-75 & 586 & 2.77 & 0.88 & & & \\
\hline & Between 76-85 & 442 & 2.75 & 0.88 & & & \\
\hline & 86 and over & 97 & 2.97 & 0.99 & & & \\
\hline \multirow{5}{*}{$\begin{array}{l}\text { Faculty Professional } \\
\text { Responsibilities }\end{array}$} & Lower than 50 & 31 & 3.39 & 0.95 & 7.10 & $.000 * *$ & $4>3$ \\
\hline & Between 51-65 & 186 & 3.75 & 0.98 & & & \\
\hline & Between 66-75 & 586 & 3.51 & 0.98 & & & \\
\hline & Between 76-85 & 442 & 3.81 & 1.00 & & & \\
\hline & 86 and over & 97 & 3.76 & 1.01 & & & \\
\hline \multirow{5}{*}{$\begin{array}{l}\text { Sexual } \\
\text { Harassment } \\
\text { Behaviours }\end{array}$} & Lower than 50 & 31 & 1.63 & 0.73 & .511 & .730 & \\
\hline & Between 51-65 & 186 & 1.66 & 0.66 & & & \\
\hline & Between 66-75 & 586 & 1.66 & 0.68 & & & \\
\hline & Between 76-85 & 442 & 1.67 & 0.70 & & & \\
\hline & 86 and over & 97 & 1.76 & 0.77 & & & \\
\hline \multirow{5}{*}{$\begin{array}{l}\text { Relationships outside } \\
\text { the Classroom }\end{array}$} & Lower than 50 & 31 & 4.20 & 1.39 & .553 & .697 & \\
\hline & Between 51-65 & 186 & 4.57 & 1.38 & & & \\
\hline & Between 66-75 & 586 & 4.56 & 1.33 & & & \\
\hline & Between 76-85 & 442 & 4.56 & 1.36 & & & \\
\hline & 86 and over & 97 & 4.61 & 1.58 & & & \\
\hline
\end{tabular}

${ }^{*} \mathrm{p}<.05 .{ }^{* *} \mathrm{p}<.01$

Table 2 shows comparison of one way ANOVA analysis results in terms of students' GPAs and faculty ethical behaviors. According to that, there are significant differences among students' perceptions about faculty 
behaviors inside the classroom $\left[\mathrm{F}_{(4,1337)}=2,75, \mathrm{p}<.05\right]$ and professional responsibilities $\left[\mathrm{F}_{(4,1337)}=7.10, \mathrm{p}<.01\right]$ in terms of their GPAs. On the other hand, there are no significant differences among students' perceptions about relationship based on self-interest, sexual harassment behaviours and relationships outside the classroom. When faculty ethical behaviors inside the classroom and professional responsibility are concerned, the students' whose GPAs are between 76-85 ( $\bar{X}=2.74)$ have more negative considerations comparing those with 66-75 GPAs $(\mathrm{p}<.01)$. In other words, students with higher GPAs consider their faculty behaviors more unethical comparing those with lower ones.

Table 3. One Way ANOVA analysis results of Establishment Dates of Colleges and Faculty Ethical Behavior

\begin{tabular}{|c|c|c|c|c|c|c|c|}
\hline Sub dimensions & $\begin{array}{c}\text { Establishment } \\
\text { Date }\end{array}$ & $\mathrm{n}$ & $\bar{X}$ & $\mathrm{sd}$ & $\mathrm{F}$ & $\mathrm{p}$ & $\begin{array}{c}\text { Difference } \\
\text { (Tukey) }\end{array}$ \\
\hline Ethical & Less than 5 years & 174 & 2.13 & 0.69 & 34.85 & $.00 * *$ & $2>4>3>6>5>1$ \\
\hline \multirow{5}{*}{$\begin{array}{l}\text { Behaviours } \\
\text { inside the } \\
\text { Classroom }\end{array}$} & Between 6-10 & 365 & 2.91 & 0.66 & & & \\
\hline & Between 11-15 & 175 & 2.62 & 0.73 & & & \\
\hline & Between 15-20 & 182 & 2.85 & 0.72 & & & \\
\hline & Between 20-25 & 252 & 2.57 & 0.67 & & & \\
\hline & 26 and over & 194 & 2.58 & 0.66 & & & \\
\hline \multirow{5}{*}{$\begin{array}{l}\text { Relationship } \\
\text { based on } \\
\text { self-interest }\end{array}$} & Less than 5 years & 174 & 2.25 & 0.73 & 7.14 & $.00^{* * *}$ & $4>2>3>1>6>5$ \\
\hline & Between 6-10 & 365 & 2.28 & 0.67 & & & \\
\hline & Between 11-15 & 175 & 2.27 & 0.76 & & & \\
\hline & Between 15-20 & 182 & 2.35 & 0.74 & & & \\
\hline & Between 20-25 & 252 & 1.95 & 0.65 & & & \\
\hline Faculty & Less than 5 years & 174 & 2.52 & 0.76 & 31.71 & $.00^{* *}$ & $2>4>6>5>3>1$ \\
\hline Professional & Between 6-10 & 365 & 3.38 & 0.75 & & & \\
\hline \multirow[t]{4}{*}{ Responsibilities } & Between 11-15 & 175 & 2.92 & 0.89 & & & \\
\hline & Between 15-20 & 182 & 3.17 & 0.77 & & & \\
\hline & Between 20-25 & 252 & 2.93 & 0.81 & & & \\
\hline & 26 and over & 194 & 3.04 & 0.75 & & & \\
\hline Sexual & Less than 5 years & 174 & 1.81 & 0.72 & 11.04 & $.00 * *$ & $4>2>3>1>5>6$ \\
\hline Harassment & Between 6-10 & 365 & 2.23 & 0.9 & & & \\
\hline \multirow[t]{4}{*}{ Behaviours } & Between 11-15 & 175 & 2.13 & 0.88 & & & \\
\hline & Between 15-20 & 182 & 2.33 & 0.84 & & & \\
\hline & Between 20-25 & 252 & 1.97 & 0.91 & & & \\
\hline & 26 and over & 194 & 1.94 & 0.74 & & & \\
\hline \multirow{6}{*}{$\begin{array}{l}\text { Relationships } \\
\text { outside the } \\
\text { Classroom }\end{array}$} & Less than 5 years & 174 & 2.05 & 0.66 & 9.17 & $.00^{* *}$ & $4>2>3>6>5>1$ \\
\hline & Between 6-10 & 365 & 2.40 & 0.61 & & & \\
\hline & Between 11-15 & 175 & 2.32 & 0.73 & & & \\
\hline & Between 15-20 & 182 & 2.41 & 0.69 & & & \\
\hline & Between 20-25 & 252 & 2.17 & 0.74 & & & \\
\hline & 26 and over & 194 & 2.25 & 0.66 & & & \\
\hline
\end{tabular}

${ }^{*} \mathrm{p}<.05 .{ }^{* *} \mathrm{p}<.01$

Table 3 presents one way ANOVA analysis results. According to establishment dates, there is also significant difference among the students' views and faculty behaviors in terms of behaviors inside the classroom $\left[\mathrm{F}_{(5,1336)}=\right.$ $34.85, \mathrm{p}<.01]$, relationship based on self-interest $\left[\mathrm{F}_{(5,1336)}=7.14, \mathrm{p}<.01\right]$, professional responsibilities $\left[\mathrm{F}_{(5,1336)}\right.$ $=31.71, \mathrm{p}<.01]$, sexual harassment $\left[\mathrm{F}_{(5,1336)}=11.04, \mathrm{p}<.01\right]$ and relationships outside the classroom $\left[\mathrm{F}_{(5,1336)}\right.$ $=9.17, \mathrm{p}<.01]$. This indicates that students from the colleges established 6-10 years ago have more negative considerations in terms of faculty behaviors inside the classroom $(\bar{X}=2.91)$ and professional responsibilities ( $\bar{X}=3.38$ ). However, students who are from newly-established colleges and those established $20-25$ years ago have more positive considerations in all sub-dimensions $(p<.5)$. 
Table 4. T-test Analysis Results in terms of GPA and Faculty Ethical Behaviors

\begin{tabular}{llcccccc}
\hline Sub-dimensions & Gender & $n$ & $\bar{X}$ & $S d$ & $t$ & $d f$ & $p$ \\
\hline \multirow{2}{*}{ Ethical behavior inside the classroom } & Female & 744 & 2.99 & 0.84 & -1.870 & 1340 & .06 \\
& Male & 598 & 3.08 & 0.82 & & & \\
Relationship based on self-interest & Female & 744 & 2.73 & 0.90 & -2.565 & 1340 & .01 \\
& Male & 598 & 2.85 & 0.86 & & & \\
\multirow{2}{*}{ Faculty Professional Responsibilities } & Female & 744 & 3.58 & 0.98 & -3.332 & 1340 & .01 \\
& Male & 598 & 3.76 & 0.97 & & & \\
Sexual Harassment Behaviours & Female & 744 & 1.55 & 0.65 & -6.850 & 1340 & .01 \\
& Male & 598 & 1.81 & 0.71 & & & \\
Relationships outside the Classroom & Female & 744 & 4.38 & 1.36 & -5.369 & 1340 & .01 \\
& Male & 598 & 4.78 & 1.35 & & & \\
\hline
\end{tabular}

$* * \mathrm{p}<.01$

Table 4 presents t-test analysis results. Despite having a significant difference in gender variable and faculty relationship based on self-interest $\left(\mathrm{t}_{(1340)}=-2.565, \mathrm{p}<0.01\right)$, faculty professional responsibilities $\left(\mathrm{t}_{(1340)}=-3.332\right.$, $\mathrm{p}<0.01)$, sexual harassment behaviours $\left(\mathrm{t}_{(1340)}=-6.850, \mathrm{p}<0.01\right)$ and relationships outside the classroom $\left(\mathrm{t}_{(1340)}=\right.$ $-5.369, \mathrm{p}<0.01)$, there is no significant difference regarding ethical behavior inside the classroom $\left(\mathrm{t}_{(1340)}=-1.870\right.$, $\mathrm{p}>0.05$ ). In general, male students consider faculty behaviors less ethical comparing their female friends in all sub dimensions.

Table 5. One Way ANOVA results of Classroom Size and Faculty Ethical Behavior

\begin{tabular}{|c|c|c|c|c|c|c|c|}
\hline Dimension & $\begin{array}{l}\text { Grade Point } \\
\text { Average }\end{array}$ & $\mathrm{n}$ & $\bar{X}$ & $\mathrm{sd}$ & $\mathrm{F}$ & $\mathrm{p}$ & $\begin{array}{l}\text { Difference } \\
\text { (Tukey) }\end{array}$ \\
\hline \multirow{4}{*}{$\begin{array}{l}\text { Ethical behavior inside the } \\
\text { classroom }\end{array}$} & Lower than 30 & 74 & 3.10 & 0.81 & \multirow{4}{*}{3.20} & \multirow{4}{*}{$.02 *$} & \multirow{4}{*}{$\begin{array}{l}3>2 \\
4>2\end{array}$} \\
\hline & Between 31-40 & 254 & 2.89 & 0.85 & & & \\
\hline & Between 41-50 & 394 & 3.07 & 0.78 & & & \\
\hline & 51 and over & 620 & 3.06 & 0.85 & & & \\
\hline \multirow{4}{*}{$\begin{array}{l}\text { Relationship based on } \\
\text { self-interest }\end{array}$} & Lower than 30 & 74 & 3.02 & 0.81 & \multirow{4}{*}{2.38} & \multirow{4}{*}{.07} & \\
\hline & Between 31-40 & 254 & 2.73 & 0.86 & & & \\
\hline & Between 41-50 & 394 & 2.75 & 0.89 & & & \\
\hline & 51 and over & 620 & 2.80 & 0.89 & & & \\
\hline \multirow{4}{*}{$\begin{array}{l}\text { Faculty Professional } \\
\text { Responsibilities }\end{array}$} & Lower than 30 & 74 & 3.63 & 0.93 & \multirow{4}{*}{7.75} & \multirow{4}{*}{$.00^{* *}$} & \\
\hline & Between 31-40 & 254 & 3.39 & 0.99 & & & $3>2$ \\
\hline & Between 41-50 & 394 & 3.74 & 0.94 & & & $4>2$ \\
\hline & 51 and over & 620 & 3.76 & 1.02 & & & \\
\hline \multirow{4}{*}{$\begin{array}{l}\text { Sexual Harassment } \\
\text { Behaviours }\end{array}$} & Lower than 30 & 74 & 1.79 & 0.68 & \multirow{4}{*}{1.56} & \multirow{4}{*}{.19} & \\
\hline & Between 31-40 & 254 & 1.61 & 0.66 & & & \\
\hline & Between 41-50 & 394 & 1.69 & 0.70 & & & \\
\hline & 51 and over & 620 & 1.66 & 0.70 & & & \\
\hline \multirow{4}{*}{$\begin{array}{l}\text { Relationships outside the } \\
\text { Classroom }\end{array}$} & Lower than 30 & 74 & 4.66 & 1.54 & \multirow{4}{*}{1.81} & \multirow{4}{*}{.14} & \\
\hline & Between 31-40 & 254 & 4.46 & 1.36 & & & \\
\hline & Between 41-50 & 394 & 4.68 & 1.33 & & & \\
\hline & 51 and over & 620 & 4.51 & 1.37 & & & \\
\hline
\end{tabular}

$* \mathrm{p}<.05 . * * \mathrm{p}<.01$

Table 3 presents one way ANOVA analysis results in terms of classroom size. According to this, there is significant difference among the students' views and faculty behaviors in terms of behaviors inside the classroom $\left[\mathrm{F}_{(3,1338)}=3.20, \mathrm{p}<.05\right]$, professional responsibilities $\left[\mathrm{F}_{(3,1338)}=7.75, \mathrm{p}<.01\right]$. However, there is no significant difference regarding faculty relationship based on self-interest, sexual harassment behaviours and relationships 
outside the classroom ( $\mathrm{p}>0.05)$. As such, students from the classes with 41-50 $(\bar{X}=3.07)$ and 51 and more ( $\bar{X}=3.06$ ) have more negative considerations regarding ethical behavior inside the classroom comparing those from classes with 31-40 students $(\bar{X}=2.89)(\mathrm{p}<.05)$. Furthermore, those from classes with 41-50 students $(\bar{X}=3.07)$ and 51 and more $(\bar{X}=3.06)$ have more negative perceptions concerning faculty professional responsibilities comparing the ones from the classes with 31-40 students $(\bar{X}=2.89)(\mathrm{p}<.05)$.

\section{Discussion}

Student perceptions about faculty ethical behaviors were evaluated in this study and a number of results were obtained. According to one of the results, students' considerations are negative concerning faculty professional behaviors. Students state that faculty give lower grades to those whom they disagree and they do not provide alternative teaching and testing procedures for students who have learning disabilities. Furthermore, faculty give exams which do not reflect the material covered/discussed and allow how much they like or dislike a student to influence the student's grades. Similar results were obtained from the qualitative part as well. Here, they claim that they are not given grades they deserve. Keith-Spiegel, Tabachnick and Allen (1993) discovered similar results in their study. They found that faculty lose their fairness and give students an A regardless the quality of their work. Morgan and Korschgen (2001) discovered that faculty gave easy tests to continue their popularity.

As soon as faculty behaviors inside the classroom are concerned, in this respect, it is alleged that faculty have some privileged students and they grade them higher. It is also claimed that faculty include false or misleading information when writing a letter of recommendation for the student, which causes their rejections from some programs. They also specify that faculty include material on a test not covered in the lectures or assigned reading. Some students even claim having been discriminated according to their ethnic, regional, gender and religious backgrounds. All these problems may stem from lack of supervision system in higher education and dysfunctional ethical standards. In the Turkish higher education system accountability does not function and faculty are not kept responsible for the behaviors and student failure. Students are given a small 15-item questionnaire to evaluate course and faculty. However, their considerations are not usually taken into account. Therefore, faculty may feel themselves free from what to do at school most of the time unless somebody complains about them.

As far as relationship based on self-interest/inappropriate exchange is concerned, students mention that faculty accept inexpensive gifts from students. However, in the qualitative part of the study, faculty are also claimed to ask small favors from students. In this respect, they may probably be considering that it these favors are innocent, but they are not perceived in the same direction by the students.

According to another result, students' considerations are totally negative in terms of faculty professional responsibilities. Results reveal that faculty teach classes without being adequately prepared that day which means going to their classes with no or little prior preparation. They also fail to maintain regularly scheduled office hours; frequently arrive late for class without advance notice (sometimes 20 minutes). They do not also get exams graded and return until 4 weeks after the exam given and they never learn any of the student's names in a relatively small class. This result is consistent with the results obtained by Branstetter and Handelsman (2000) and Owen and Zwahr-Castro (2007). They found that that ninety percent of the teaching psychologists go to their classes teaching material not mastered and teaching without adequate preparation. These ethical problems may stem from workload of academic staff (approx.25-30 teaching hours/week) and faculty-student ratio (1/85). However, Ugurlu (2008) found positive perceptions concerning faculty professional responsibilities. Morgan and Korschgen (2001) discovered that faculty did not perform their professional responsibilities fully. In the original scale, Schnake at al., (2004) identified 5 dimensions to determine ethical climate of the institution in terms of student retention, class attendance, and stress and student performance. That study discovered that ethical behaviors are related to students' success.

When dating/sexual harassment is concerned, opposing results were obtained from both quantitive and qualitative parts. Here, while students consider faculty behaviors as ethical in the quantitive part, their considerations are unethical in the qualitative part. In this sense, faculty are claimed to have a tendency to imply sexual things in their conversations and behaviors by touching female students physically, pulling their hair and hugging them. Especially male students' perceptions are more negative in this part. This difference may stem from research methodology. Here, qualitative method is used which allows researchers to get in-depth answers from the participants during a more sincere interview process. The difference between male and female student views may also be because of the pressure from the society. Female student cannot explain sexual harassment behaviors they encounter easily in the Turkish culture although they experience such implications and behaviors. Similar results were discovered by Branstetter and Handelsman, (2000). They state that a number of behaviors 
emerge as exceptionally controversial, especially relating to sexual issues like being sexually attracted to students, engaging in sexual fantasies about students, requiring students to use aversive procedures with animals, and becoming sexually involved with students only after they have completed the course. Tabachnick et al., (1991) also found similar results. According to them, male teachers also tend to rate more sexual behaviors as ethical and practice more sexually related behaviors. Similarly, Morgan and Korschgen (2001) also discovered that faculty have sexual involvements with their students.

Finally, when faculty behaviors outside the classroom are concerned, students' considerations are also negative. In this respect, they state that faculty accept their invitations to parties and they also begin on-going friendships with students in their classes. In a similar study, Pascarella and Terenizini (1991) reveal that faculty interactions with students outside of the classroom are positively related to students 'academic and social development. Probably, they may consider going out to a cafe as a normal way of behavior to socialize with their students, but it is not considered an acceptable way of behavior in the Turkish society due to some cultural beliefs and patterns.

As far as gender variable is concerned there are differences in students' opinions. According to this, male students consider faculty behaviors less ethical comparing their female counterparts in all sub dimensions. There are some cultural concerns about it. It can be said that the students who study at department of teacher colleges come from socio-economically low and conservative backgrounds. For this reason, they may be feeling themselves critical about formal faculty-female student interactions or relationships. As the natures of their conservative background, these kinds of interactions are unacceptable, male students feel themselves responsible for defending their female counterparts. In this conservative environment, it is unacceptable if faculty have a private relationship with their students and their intention to attend a party where students go. In the Turkish society, faculty are perceived as sophisticated and respectable people with their high status. Therefore, they are expected to have formal relationships with their students. They are not supposed to establish close relationships especially with their female students as it can be assumed as sexual harassment.

Regarding classroom size variable, research results reveal that while classroom size increases, students' perceptions become more negative in terms of faculty ethical behaviors inside the classroom and faculty professional responsibilities. According to the results, students think that faculty behave less ethical towards them. As classrooms get more crowded (40+), faculty may not have a chance to memorize their students' names and call them by their names. Moreover, it is considered that the more crowded the classroom gets, the more difficult they focus on their lessons and control unwanted behaviors during the class. This may be one of the indicators of their failure in performing their professional responsibilities. In this respect, they cannot apply contemporary methods like cooperative, constructivist; problem based teaching technics in these crowded classrooms. Instead, they tend to implement didactic methods to catch up with the pacing and deal with the crowd. They cannot ask if students understand the lesson fully after the class. Furthermore, faculty may not have enough time for each student in their office hours as well. It is evaluated that these problems may be the causes of the students' negative perceptions obtained here.

On the other hand, when students' GPAs are concerned, there is no significant difference among students' perceptions about faculty behaviors in terms of relationship based on self-interest, sexual harassment and relationships outside the classroom. It is considered that people's ethical perceptions are usually related to moral and cultural origin and therefore, academic success does not hide students" views.

\section{Conclusion}

It can be concluded from this study that there are some ethical problems at academia of this sample, especially in terms of faculty behaviors inside the classroom and faculty professional behaviors. According to the results obtained here, faculty do not fulfill their professional roles properly by neglecting their basic duties like going to their classes on time, evaluating them fairly, returning exams in time, giving exams that contain subjects that are not covered or assigned advance and conducting their classes properly. The results also reveal that faculty have some unethical behaviors inside the classroom like having favorite students to grade and behaving some of the students impolitely. Furthermore, there are also some minor unethical problems in relationships based on self -interest, dating-sexual harassment and behaviors outside the classroom sub dimensions, but they are not common in general.

Faculty behaviors indicate significant differences in terms of establishment dates of the universities. Surprisingly, students from newly-established ones have more positive considerations about faculty behaviors comparing those from older colleges. There are also significant differences between faculty behaviors and students' GPAs. According to that students with higher GPAs have more negative perceptions than those with lower GPAs about 
faculty behaviors. It can be concluded that faculty ethical behaviors are vital for students as Walker (2012) puts the intervention of an ethics class informed students' cognitive and affective perceptions based on individual value and belief systems, strengthened student's ability to remain open-minded and reconsider previous beliefs and actions from a 360 degree perspective, and increased student's ability to apply new information to ethical dilemmas. The recommendations reached in this study are below:

- There should be ethical boards at schools with full participation of faculty, students and administrative staff.

- Ethical rules should be developed and both faculty and students should be informed about the importance of them

- Faculty should inform the students about the content of the lesson, the course and assessment procedure.

- Faculty should assess students fairly without being affected personal feelings.

- Their professional responsibilities should be observed by administration.

- In order to collect student complaints about faculty ethical behaviors, suggestion boxes should be put at school.

- Faculty promotion should also be based on ethical behaviors.

\section{References}

APA. (2002). Ethical principles of psychologists and code of conduct. American psychological association, 57(12), 1060-1073. http://dx.doi.org/10.1037/0003-066X.57.12.1060

Aurin, K., \& Maurer, M. (1993). Forms and dimensions of teachers' professional ethics-case studies in secondary schools. Journal of moral education, 22(3), 1-29. http://dx.doi.org/10.1080/0305724930220307

Bailey, K. D. (1994). Methods of social research. Fourth Edition. A Division of Macmillan, Inc. New York, N.Y.

Barcena, F., \& Gil, F. (1993). The ethical dimension of teaching: A review and a proposal. Journal of moral education, 22(3), 1-13. http://dx.doi.org/10.1080/0305724930220305

Baumgarten, E. (1982). Ethics in academic profession, a Socratic view. Journal of higher education, 53(3), 282-295. http://dx.doi.org/10.2307/1981748

Bebeau, M. J. (1993). Designing an outcome-based ethics curriculum for professional education: Strategies and evidence. Journal of moral education, 22(3), 1-15. http://dx.doi.org/10.1080/0305724930220309

Bersoff, D. N., \& Koeppl, P. M. (1993). The relation between ethical code and moral principles. Ethics \& behavior, 3(3-4), 345-357. http://dx.doi.org/10.1080/10508422.1993.9652112

Biaggio, M., Paget, T. L., \& Chenoweth, M. S. (1997). A model for ethical management of faculty student relationships. Professional psychology: Research and practice, 28, 184-189. http://dx.doi.org/10.1037/0735-7028.28.2.184

Blevins-Knabe, B. (1992). The ethics of dual relationships in higher education. Ethics\& behavior, 2(3), 151-163. http://dx.doi.org/10.1207/s15327019eb0203_2

Bogdan, R. C., \& Biklen, S. K. (1998). Qualitative research for education: An introduction to theory and methods. ( $3^{\text {rd }}$ ed.). Boston, MA: Allyn \& Bacon.

Branstetter, S. A., \& Handelsman, M. M. (2000). Graduate teaching assistants: Ethical training, beliefs, and practices. Ethics \& behavior, 10(1), 27-50. http://dx.doi.org/10.1207/S15327019EB1001_3

Brown, T. A. (2006). Confirmatory factor analysis for applied research. The Guilford Press, New York.

Burgess, J. P. (2011). Contribution to the workshop: Ethical issues in security research a practical approach. European commission, 1-4.

Buyukozturk, S., Kilic, Cakmak, E., Akgun, O. E., Karadeniz, S., \& Demirel, F. (2008). Bilimsel arastirma yontemleri. Ankara: Pegem Yayinlari.

Carr, D. (2000). Professionalism and ethics in teaching. Routledge.

Cassell, J., \& Jacobss, S. E. (1987). Handbook on ethical issues in anthropology. Washington, American Anthropological Association.

Chalk, R., Frankel, M. S., \& Chafer, S. B. (1980). Professional ethics activities in the scientific and engineering societies. Washington D.C.: American Association for the Advancement of Science.

Churchill, L. R. (1982). The teaching of ethics and moral values in teaching: Some contemporary confusions. The journal of higher education, 53(3), 296-306. http://dx.doi.org/10.2307/1981749 
Colnerud, G. (1997). Ethical conflicts in teaching. Teaching and teacher education, 13(6), 627-635. http://dx.doi.org/10.1016/S0742-051X(97)80005-4

Cothran, D. J., \& Ennis, C. D. (1997). Students' and teachers' perceptions of conflict and power. Teaching and teaching education, 13(5), 541-553. http://dx.doi.org/10.1016/S0742-051X(97)85542-4

Dika, A., \& Hamiti, M. (2011). Challenges of implementing the ethics through the use of information technologies in the university. WCES-2011, Procedia social and behavioral sciences, 15, 1110-1114.

Dill, D. (1982). The structure of the academic profession: Toward a definition of ethical issues. The journal of higher education, 53(3), 255-267. http://dx.doi.org/10.2307/1981746

Epstein, R. (1998). Redesigning the world: Ethical questions about genetic engineering, Economics, 27, 699-708.

Fritz, O., \& Wolfgang, A. (1993). Trust in advance: On the professional morality of teachers. Journal of moral education, 22(3), 253-275. http://dx.doi.org/10.1080/0305724930220306

Gercek, H., Guven, M. H., Ozdamar, S. O., Yelken, T. Y., \& Korkmaz, T. (2011). Ethical principles, responsibilities, and codes of conduct in higher education institutions. Journal of higher education and science, 1(2), 80-88. http://dx.doi.org/10.5961/jhes.2011.013

Glaser, B. (1992). Theoretical sensitivity: Advances in the methodology of grounded theory. Mill Valley, CA.: Sociology Press.

Haas, L. J., Malouf, J. L., \& Mayerson, N. H. (1988). Personal and professional characteristics as factors in psychologists' ethical decision making, professional psychology. Research and practice, 19, 35-42.

Hall, D. T. (1973). Changing correlates of job involvement in three career stages. Journal of vocational behavior, $18(2), 138-144$.

Haynes, J. (2002). Freedom and the urge to think in philosophy with children. Gifted education international, 22(2-3) 229-237.

Jacob, S., \& Hartshorne, T. S. (2003). Ethics and law for school psychologists (4th ed.). New Jersey: John Wiley $\&$ Sons, Inc.

Johnson, A. S. (2007). An ethics of access: Using life history to trace pre-service teachers' initial viewpoints on teaching for equity. Journal of teacher education, 58(4), 299-335. http://dx.doi.org/10.1177/0022487107305604

Joseph, P., \& Efron, S. (1993). Moral choices/moral conflicts: Teachers' self-perceptions. Journal of moral education, 22(3), 1-28. http://dx.doi.org/10.1080/0305724930220303

Keith-Spiegel, P. C., Tabachnick, B. G., \& Allen, M. (1993). Ethics in academia: Students' view of professors' actions. Ethics \& behavior, 3, 149-162. http://dx.doi.org/10.1207/s15327019eb0302_1

Keith-Spiegel, P., Whitley, B. E., Jr., Balogh, D. W., Perkins, D. V., \& Wittig, A. F. (2002). The ethics of teaching: A casebook (2nd ed.). Mahwah, NJ: Lawrence Erlbaum.

Kitchener, K. S. (1985). Ethical principles and ethical decisions in student affairs, In H. J. Canon, \& Brown (Eds.), New directions for student services. Applied ethics, Josey-Bass, 17-29. http://dx.doi.org/10.1002/ss.37119853004

Kline, R. B. (2011). Principles and practice of structural equation modeling (3rd ed.). The Guilford Press, New York.

Kompf, M. (1993). Ethical considerations in teacher disclosure: Construing persons and methods. Teaching and Teacher Education, 9(6), 519-528. http://dx.doi.org/10.1016/0742-051X(93)90035-F

Lazarus, A. A. (1994). How certain boundaries and ethics diminish therapeutic effectiveness. Ethics \& behavior, 4, 255-261. http://dx.doi.org/10.1207/s15327019eb0403_10

Mayring, P. (2000). Qualitative content analysis, forum. Online journal qualitative social research, 1(2), 1-10.

Morgan, B. L., \& Korschgen, A. J. (2001). The ethics of faculty behavior: students' and professors' views. College student journal, 35(3), 418-423.

NASSP. (1999). Character education special issue. National association of secondary school principals, 83(609), $1-122$.

OUP. (2011). The Oxford advanced learner's Dictionary (7th Ed.). Oxford, Oxford University Press. 
Owen, P. R., \& Zwahr-Castro, J. (2007). Boundary issues in academia: student perceptions of faculty-student boundary crossings. Ethics \& behavior, 17(2), 117-129. http://dx.doi.org/10.1080/10508420701378065

Ozcan, K., \& Balyer, A. (2012). Ogretim elemanlari etik davranislari olceginin Turkceye uyarlanmasi. Adiyaman universitesi sosyal bilimler dergisi, 5(10), 345-376.

Pascarella, E. T., \& Terenzini, P. T. (1991). How college affects students: findings and insights from twenty years of research. San Francisco: Jossey-Bass.

Robertson, E., \& Grant, G. (1982). Teaching and ethics, an epilogue. Journal of higher education, 53(3), 345-356. http://dx.doi.org/10.2307/1981753

Rupert, P. A., \& Holmes, D. L. (1997). Dual relationships in higher education. Journal of higher education, 68(6), 660-678. http://dx.doi.org/10.2307/2959967

Sandler, J. C., \& Russell, B. (2005). Faculty-student collaborations: Ethics and satisfaction in authorship credit. Ethics \& behavior, 15(1), 65-80. http://dx.doi.org/10.1207/s15327019eb1501_5

Schnake, M., Fredenberger, W., \& Dumler, M. P. (2004). Dimensions of student perceptions of faculty ethical behevior: Refining a measure and reletionships with selected outcome variables. Academy of educational leadership journal, 8(2), 1-16.

Smith, D., \& Fitzpatrick, M. (1995). Patient-therapist boundary issues: An integrative review of theory and research. Professional psychology: research and practice, 26, 499-506. http://dx.doi.org/10.1037/0735-7028.26.5.499

Smith, R. (1996). Essential ethical considerations in education. Education, 117(1), 17-21.

Solomon, R. S. (1984). Ethics: A brief introduction. New York: McGraw-Hill.

Strike, K. A. (1990). Teaching ethics to teachers: What the curriculum should be about. Teaching \& teacher education, 6(1), 47-53. http://dx.doi.org/10.1016/0742-051X(90)90006-Q

Svinicki, M. D. (1994). Lecture handout: Teaching with the learner in mind. Office of Faculty and TA development, The Ohio State University.

Tabachnick, B. G., Keith-Spiegel, P., \& Pope, K. S. (1991). Ethics of teaching, beliefs and behaviors of

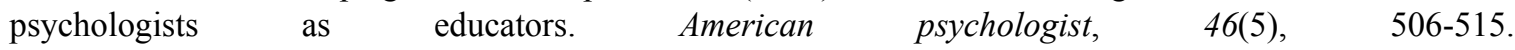
http://dx.doi.org/10.1037/0003-066X.46.5.506

Tebligler Dergisi. (2003). Milli Egitim Bakanligi, 2552 Sayili Tebligler Dergisi Ilkogretim Kurumlari Yonetmeligi, Eylul 2003.

Tippins, D. J., \&Tobin, K. G. (1993). Ethical decisions at the heart of teaching: Making sense from a constructivist perspective. Journal of moral education, 22(3), 1-29. http://dx.doi.org/10.1080/0305724930220304

Ugurlu, T. (2008). Lise son sinif ogrencilerinin ogretmenlerinin etik davranislarina iliskin algilari, Kastamonu egitim dergisi, 16(2), 367-378.

Walker, M. (2013). Evaluating the intervention of an ethics' class in students' ethical decision-making: a summative review. International education studies, 6(1), 10-25.

Wilson, E. K. (1982). Power, pretense, and piggybacking: Some ethical issues in teaching. Journal of higher education, 53, 268-281. http://dx.doi.org/10.2307/1981747

Yaman, E., Mermer, E. Ç., \& Mutlugil, S. (2009). Ilkogretim okulu ogrencilerinin etik davranislara iliskin gorusleri: nitel bir arastirma. Degerler egitimi dergisi, 7(17), 93-108.

Yildirim, A., \& Simsek, H. (2000). Sosyal bilimlerde nitel arastirma yontemleri. Seckin Yayinlari, Ankara.

Zabiollah, R., Elmore, C. R., \& Szendi, J. Z. (2001). Ethical behavior in higher educational institutions: The role of the code of conduct. Journal of business ethics, 30, 171-183. http://dx.doi.org/10.1023/A:1006423220775 